\title{
Több mint 50 év tapasztalat a congenitalis szívbetegek ellátásában egy magyar egyetemi központban
}

\author{
A CSONGRÁD Regiszter alapadatai
}

\author{
Havasi Kálmán dr. ${ }^{1}$ - Kalapos Anita dr. ${ }^{1}$ - Berek Krisztina dr. ${ }^{1}$ \\ Domsik Péter dr. ${ }^{1}$ - Kovács Gábor dr. ${ }^{2}$ - Bogáts Gábor dr. ${ }^{2}$ \\ Hartyánszky István dr. ${ }^{2}$ - Kertész Erzsébet $d r .^{3}$. Katona Márta dr. ${ }^{3}$ \\ Rácz Katalin dr. ${ }^{3}$ - Csanády Miklós dr. ${ }^{1}$ \\ Forster Tamás dr. ${ }^{1}$ - Nemes Attila dr. ${ }^{1}$ \\ Szegedi Tudományegyetem, Általános Orvostudományi Kar, Szent-Györgyi Albert Klinikai Központ, \\ ${ }^{1}$ II. Belgyógyászati Klinika és Kardiológiai Központ, ${ }^{2}$ Kardiológiai Központ, Szívsebészeti Osztály, \\ ${ }^{2}$ Gyermekgyógyászati Klinika és Gyermek Egészségügyi Központ, Szeged
}

\begin{abstract}
Köszönhetően az egyre tökéletesedő mútéti technikáknak és a technikai fejlődésnek, ma már sok, congenitalis szívbetegségben szenvedő egyén éri meg a felnőttkort. Ezeknek a betegeknek a jobb ellátása céljából egy regiszter összeállítása mellett döntöttek, amely jelenleg 2770 beteg 3043 mútéti beavatkozásának adatait tartalmazza, amelyeket közel 30-féle diagnózis miatt végeztek. Jelen tanulmány célja a regiszter-összeállítás okainak és alapjainak bemutatása. Orv. Hetil., 2015, 156(20), 794-800.
\end{abstract}

Kulcsszavak: regiszter, congenitalis szívbetegség

\begin{abstract}
More than 50 years' experience in the treatment of patients with congenital heart disease in a Hungarian university hospital
\end{abstract}

\section{The basics of the CSONGRAD Registry}

Due to improvement of surgical techniques and technical developments several patients with congenital heart disease have grown up. It has been decided to create a registry for their more precise treatment. This now includes 2770 patients with data of 3043 operations with almost 30 diagnoses. The purpose of this review is to demonstrate the facts leading to create this register and the basics of this.

Keywords: registry, congenital heart disease

Havasi, K., Kalapos, A., Berek, K., Domsik, P., Kovács, G., Bogáts, G., Hartyánszky, I., Kertész, E., Katona, M., Rácz, K., Csanády, M., Forster, T., Nemes, A. [More than 50 years' experience in the treatment of patients with congenital heart disease in a Hungarian university hospital. The basics of the CSONGRAD Registry]. Orv. Hetil., 2015, $156(20), 794-800$.

(Beérkezett: 2015. február 13.; elfogadva: 2015. március 19.)

A veleszületett szívfejlődési rendellenességek az egészen enyhe, panaszokat nem okozó eltérésektől az igen összetett, jelentős tünetekkel járó vagy akár az élettel összeegyeztethetetlen elváltozásokig rendkívül sokféle képet mutathatnak. Az egyszerü, enyhe veleszületett szívhibák a felnőttkorban gyakran véletlenül, mellékleletként kerülnek felfedezésre, míg bizonyos eltérések már a születés pillanatában egyértelmúen jelzik a szív és nagyerek 
fejlódésében megjelenő problémát. Évtizedekkel ezelőtt az összetett, súlyos szívfejlődési rendellenességgel születettek jelentős része nem élte meg a kisgyermekkort sem. Az új, egyre tökéletesedő mútéti technikáknak és a technikai fejlődésnek köszönhetően azonban manapság már igen sok congenitalis vitium kezelhetô mútéti úton [1]. $\mathrm{Az}$ így megoperált betegeket sokáig a gyermekkardiológián gondozták-gondozzák, mivel azonban egyre többen érik el a felnőttkort, átkerülnek a felnőtt kardiológiai ellátórendszerbe. Ismert tapasztalati tény azonban, hogy relatíve új betegcsoport lévén, a felnőttkardiológusoknak sok szempontból kihívást jelent az ilyen betegek szakszerü kezelése és követése.

Általánosságban elfogadott tény, hogy a minél precízebb ellátás érdekében elóször is érdemes az adott beteg eredeti vitiumának, mútéti megoldásának ismerete. A hosszú távú követés kapcsán ugyanis tisztában kell lenni azzal, hogy az adott beteg esetében melyek lehetnek a buktatók és a várható, hosszú távon jelentkező szövődmények. A felnőttkort megért, congenitalis vitiummal bíró betegek gondozásával kapcsolatban a Kardiológiai Szakmai Kollégium ajánlása megfogalmazza azt, hogy milyen típusú vitiummal milyen intézetben érdemes az ellenőrzéseket elvégezni [2]. Ennek megfelelően az öszszetett, súlyos esetek ellenőrzése a klinikai centrumok feladata, így intézetünk, a Szegedi Tudományegyetem, ÁOK, II. számú Belgyógyászati Klinika és Kardiológiai Központ már évtizedek óta lát el felnőtt korú, veleszületett szívbetegségben szenvedő betegeket. A gyermekkardiológia, a szívsebészet és a felnőtttkardiológia (azon belül az invazív kardiológia, az elektrofiziológia és a képalkotó diagnosztika) jó munkakapcsolatának köszönhetóen sok congenitalis szívbeteget diagnosztizál és kezel.

Annak érdekében, hogy a klinikánk gondozásában levő betegek felnóttkori ellátása során minél több adat álljon rendelkezésünkre, a skandináv regiszterekhez hasonlóan elkészítettük a CSONGRÁD Regisztert (Registry for $C(S) O N G$ enital caRdiAc Disease patients at the University of Szeged) $[3,4,5]$. A regiszter összeállítása megfelelt az 1975-ös Helsinki Deklaráció etikai elvárásainak, és a helyi etikai bizottság elfogadta (regisztrációs szám: 125/2014). Az adatbázisban az 1961 és 2014. június 30. között az egyetemünkön észlelt és kezelt congenitalis szívbetegek klinikai adatait rögzítettük, amelyekhez információkat az alábbi intézetek nyújtottak:

- Szegedi Tudományegyetem (SZTE), ÁOK, II. számú Belgyógyászati Klinika és Kardiológiai Központ;

- SZTE, ÁOK, Kardiológiai Központ, Szívsebészeti Osztály;

- SZTE, ÁOK, Gyermekgyógyászati Klinika és Gyermek Egészségügyi Központ.

A regiszter a jelen közlemény írásának idején (2015. február 10.) több mint 2700 beteg több mint 3000 mútéti beavatkozásának adatait tartalmazza, amelyeket közel 30-féle diagnózis miatt végeztek; 1263 esetben felnőttet, 1780 esetben gyermeket operáltak.

\section{A kezdetek}

A Szegedi Orvostudományi Egyetemen a congenitalis szívbeteg gyermekek ellátása során az 1950-es évekig szinte kizárólag a fizikális vizsgálat (esetleg EKG, röntgen) állt rendelkezésre. Az invazív hemodinamikai vizsgálatok megkezdése nyújtotta az első olyan diagnosztikai lehetőséget, amely a fizikális vizsgálat során felmerült diagnózist megerősíthette. A Hetényi professzor úr által vezetett I. számú Belgyógyászati Klinikán 1950-től múködött az akkori viszonyoknak megfelelóen korszerúnek mondható hemodinamikai laboratórium Halmágyi Dénes vezetésével. A szívkatéteres vizsgálatok bevezetése volt a feltétele annak, hogy megkezdődhessen a veleszületett szívbetegek egy részének szívsebészeti kezelése. Az első szívmútétet Szegeden 1955-ben végezték a mai I. számú Belgyógyászati Klinika 3. emeletén elhelyezett Szegedi Orvostudományi Egyetem, Szív- és Érsebészeti Osztályon, majd a szívsebészet 1958-tól az I. számú Sebészeti Klinikán folytatta munkáját [6]. Kezdetben heti egy alkalommal történtek a szívmútétek, amelyeket megelőzően a szívkatéteres vizsgálatot maguk a szívsebészek végezték Felkai Béla részvételével. A mútétek egy része felnőtteken, másik része gyermekeken történt. Már akkoriban, köszönhetően a gyermekkardiológia és a szívsebészet közötti jó munkakapcsolatnak, a veleszületett szívbetegségben szenvedő gyermekek ellátásában jól múködő betegutak épültek ki. A gyermekkardiológusok fizikális vizsgálat során szûrték ki a veleszületett szívbetegségben szenvedő gyermekeket, majd elvégezték a szívkatéterezést és tájékoztatták a gyermekek szüleit. A kivizsgálást követően a gyermekeket a szívsebészeti osztályra vették fel, ahol elvégezték a szükséges beavatkozást, a mútétet követô egy nap múlva pedig ismét a gyermekklinikán folyt a kis betegek további ápolása és kezelése. Veleszületett szívbetegség miatt rutinszerúen 1962 óta végeznek szívmútéteket Szegeden, kezdetben Kovács Gábor, jelenleg Bogáts Gábor vezetésével. Eleinte, szív-tüdő készülék híján, csak zárt mütétekre került sor (coarctatio aortae $[\mathrm{CoA}]$, ductus arteriosus persistens [PDA] stb.). Az első, felnőtteken alkalmazható szív-tüdô készülék 1962-ben került Szegedre, azóta történnek nyitott szívmútétek. Mivel az eszköz tisztítása, sterilizálása egy napot vett igénybe, a heti egy mútéti nap mellett ez a probléma akkoriban megoldhatónak bizonyult.

Az évek során egyre bővült a mútéti kapacitás, és a szívsebészek egy-egy nappal többet használhatták a mứtőt. Ezzel párhuzamosan a szívkatéterezéses vizsgálatok elvégzését fokozatosan átvették a gyermekkardiológusok. A szív-tüdő készülékeket gyártó PEMCO cég akkori vezetője egy amerikai magyar, Köteles Béla volt, akinek a segítségével 1967-ben egy új készülék került a szegedi szívsebészetre. Ez a készülék már lehetôvé tette a nyitott szívmútétek elvégzését csecsemókön is. A szívsebészet akkori vezetője, Kovács Gábor professzor több külföldi tanulmányúton szerzett tapasztalatát építette be a munkába, így igen jó mortalitási arányokat sikerült elérni. Szá- 
1. táblázat | Mútéti technikák, amelyeket először Szegeden alkalmaztak

\begin{tabular}{|c|c|c|}
\hline \multirow{2}{*}{$\begin{array}{l}\text { Mútét/beavatkozás } \\
\text { Percutan artériás katéterezés, és transzszeptális balszívfél-katéterezés }\end{array}$} & \multicolumn{2}{|c|}{ Mútét ideje } \\
\hline & 1961 & Magyarországon először \\
\hline $\begin{array}{l}\text { A transventricularis mitralis conmmissurorhexis (commissurotomia) technikája a Tubbs-dilatátort } \\
\text { használva }\end{array}$ & 1964 & Magyarországon először \\
\hline $\begin{array}{l}\text { Mütét utáni rutinszerü lélegeztetés az intratrachealis tubuson keresztül, aorta ascendens kanülálása, } \\
\text { arteria femoralis kanülálása a posztoperatív monitorozáshoz, vérgázok rendszeres vizsgálata, } \\
\text { posztoperatív masszív káliumpótlás }\end{array}$ & 1966 & Magyarországon először \\
\hline Nagyér-transzpozícióban csecsemókorban Rashkind-katéterrel pitvari septostomia & 1967 & Magyarországon először \\
\hline Vena pulmonalis totális anomalis drenázs korrekciója & 1968 & Magyarországon először \\
\hline $\begin{array}{l}\text { Sertés-aortabillentyú kipreparálás után dacronszövettel borított keretre varrva és savanyú } \\
\text { formalinnal tartósítva }\end{array}$ & 1968 & Kelet-Európában először \\
\hline Blalock-Hanlon-műtét (pitvari septumdefektus készítése zárt műtéttel) & 1968 & Magyarországon először \\
\hline Első Mustard-mútét & 1969 & Kelet-Európában először \\
\hline Interruptio aortae mütéte múanyag protézissel az aorta ascendens és descendens között & 1970 & Magyarországon elsőször \\
\hline Magyar készítésű (saját kezdeményezésre), kötött poliészterszövet intracardialis alkalmazásra & 1972 & Magyarországon először \\
\hline Első Mustard-mútét csecsemőnél & 1973 & Kelet-Európában először \\
\hline Vena pulmonalis totalis anomalis drenázs csecsemókori (6 hó) korrekciója & 1975 & Magyarországon először \\
\hline Rastelli-mütét (16 éves gyermeken) bioprotézist tartalmazó dacronprotézissel & 1975 & Kelet-Európában először \\
\hline Konno-mútét & 1976 & Kelet-Európában először \\
\hline Rastelli-mútét csecsemőben & 1976 & Kelet-Európában először \\
\hline Fallot-tetralógia korrekciója transannularis folttal és bioprotézis ültetése a pulmonalis szájadékba & 1978 & Európában először \\
\hline Ductus Botalli formalinozás újszülöttekben & 1979 & Magyarországon először \\
\hline $\begin{array}{l}\text { Fontan típusú műtét (Kreutzer-módosítás: jobb fülcse-széles anastomosis - arteria pulmonalis } \\
\text { fötörzshöz) }\end{array}$ & 1983 & Magyarországon először \\
\hline Ventricularis septumdefektushoz társult aortainsufficientia plasztikai megoldása - Trusler-plasztika & 1983 & Magyarországon először \\
\hline Retrográd cristalloid cardioplegia a sinus coronariuson keresztül (rutinszerû alkalmazása) & 1984 & Magyarországon először \\
\hline Truncus arteriosus csecsemőkorban: Rastelli-műtét homografttal való megoldása & 1984 & Magyarországon elöször \\
\hline Módosított Blalock-Taussig-műtét vena saphena homografttal & 1989 & Világon először \\
\hline
\end{tabular}

mos mütéti típust a szegedi szívsebészeten alkalmaztak először Magyarországon (némelyt Kelet-Európában, sőt a világon), ezek listáját az 1 . táblázatban tüntettük fel. Példaként említenénk, hogy kamrai septumdefektussal és pulmonalis obstrukcióval járó nagyér-transzpozíció (TGA) korrekciójára szolgáló Rastelli-mütétet, a Fontan-mútét egyik változatát, az úgynevezett Kreutzermútétet, valamint a Rashkind-féle septostomiát is Szegeden alkalmazták először. A TGA pitvari szintú korrekciójára Magyarországon első ízben itt történt Mustard-mútét 1969-ben, majd 1985-ig még 36 beteget operáltak ezzel a módszerrel. A TGA mútéti megoldására 1985-től az úgynevezett Senning-technikát alkalmazták, amely műtéttípusból 37-et végeztek. A TGA ellátásában 1992 óta a switch-technika jön szóba. Az 1970-es években több hónapig mútőfelújítás miatt nem operáltak a budapesti Tűzoltó Utcai Gyermekklinikán, amely a veleszületett szívfejlődési rendellenességek ellátásában akkor nagy centrumnak számított. Ennek következtében az országból az összes gyermeket Szegeden operálták. Ez a magyarázata annak, hogy relatíve sok congenitalis szívmütét történt akkoriban Szegeden.
A munkacsoport 1983-ban homograftok preparálására és tartósítására alkalmas rendszert dolgozott ki, amelyet azóta is alkalmaz, lehetőséget biztosítva számos, homograftbeültetéssel járó mútét elvégzésére. A leggyakoribb diagnózisok aránya és azok előfordulása 10 éves lebontásban az 1 . ábrán és a 2. és 3. táblázatban láthatók. A reoperációk arányát a 2 ábra mutatja.

\section{Beteggondozás napjainkban}

A jelenlegi gyakorlat szerint a betegeink nagy részét az SZTE, ÁOK, Gyermekgyógyászati Klinika Kardiológiai ambulanciája irányítja intézetünkbe, néhány esetben pedig vidéki kardiológiai osztályok. Ellátási rendszerünk, a betegek gondozása teammunkára épül. Rendelkezésünkre áll aritmológus, hemodinamikus szakember, gyermekkardiológus, szívsebész, echokardiográfus, sőt amennyiben öröklődési hajlam felmerül, magzati szívultrahang is. Egy új vizsgálat keretében magzati 3D echokardiográfia elvégzésére is lehetőség van [7]. Amennyiben a felnőtt betegeknél gyermekvállalás kérdé- 

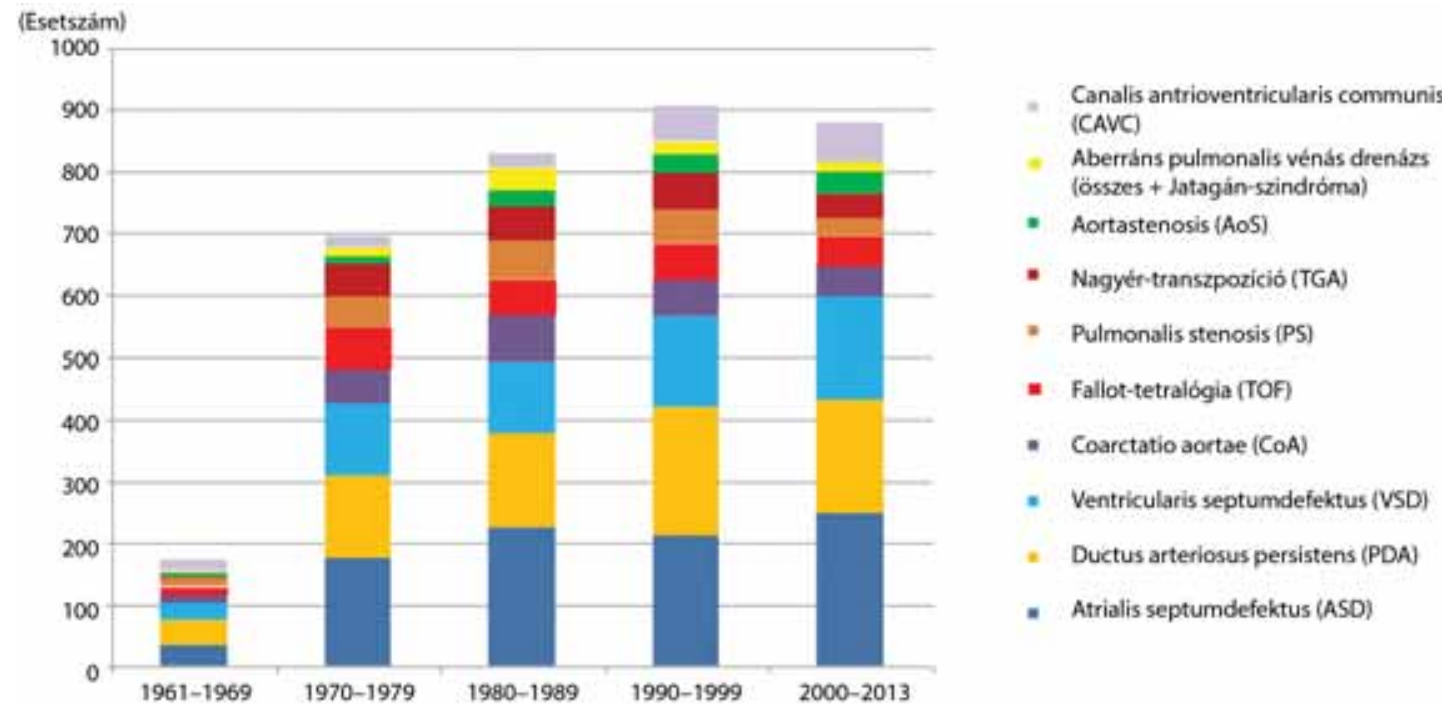

1. ábra

A Szegeden operált congenitalis szívbetegek száma tízéves lebontásban a diagnózisnak megfelelően. Amint az ábrán látható, kezdetben zárt szívműtétek történtek, majd 1967 után a szív-tüdő készülék segítségével nyitott szívmútétek elvégzése is lehetővé vált, így az 1970-es években jelentősen megemelkedett a mútétek száma. Később komplex vitiumokat is sikeresen operáltak, és az 1980-as évektől kezdve az összetett congenitalis vitium miatt operált betegek aránya is jelentősen megnőtt

2. táblázat |A leggyakrabban végzett mútétek évtizedes lebontásban

\begin{tabular}{|c|c|c|c|c|c|c|c|}
\hline Sorszám & Congenitalis szívbetegség & $1961-1969$ & $1970-1979$ & 1980-1989 & 1990-1999 & $2000-2013$ & $\begin{array}{l}\text { Mútéttípu- } \\
\text { sok száma } \\
\text { összesen }\end{array}$ \\
\hline 1. & Atrialis septumdefektus (ASD) & 34 & 176 & 226 & 212 & 248 & 896 \\
\hline 2. & Ductus arteriosus persistens (PDA) & 40 & 134 & 151 & 208 & 184 & 717 \\
\hline 3. & Ventricularis septumdefektus (VSD) & 28 & 114 & 115 & 147 & 165 & 569 \\
\hline 4. & Coarctatio aortae (CoA) & 14 & 58 & 76 & 57 & 51 & 256 \\
\hline 5. & Fallot-tetralógia (TOF) & 13 & 65 & 57 & 61 & 48 & 244 \\
\hline 6. & Pulmonalis stenosis (PS) & 14 & 51 & 64 & 54 & 29 & 212 \\
\hline 7. & Nagyér-transzpozíció (TGA) & 2 & 52 & 55 & 58 & 39 & 206 \\
\hline 8. & Canalis atrioventricularis communis (CAVC) & 18 & 19 & 23 & 57 & 62 & 179 \\
\hline 9. & Aortastenosis (AoS) & 7 & 13 & 26 & 32 & 36 & 114 \\
\hline 10. & Aberráns pulmonalis vénás drenázs & 3 & 14 & 36 & 20 & 17 & 90 \\
\hline
\end{tabular}

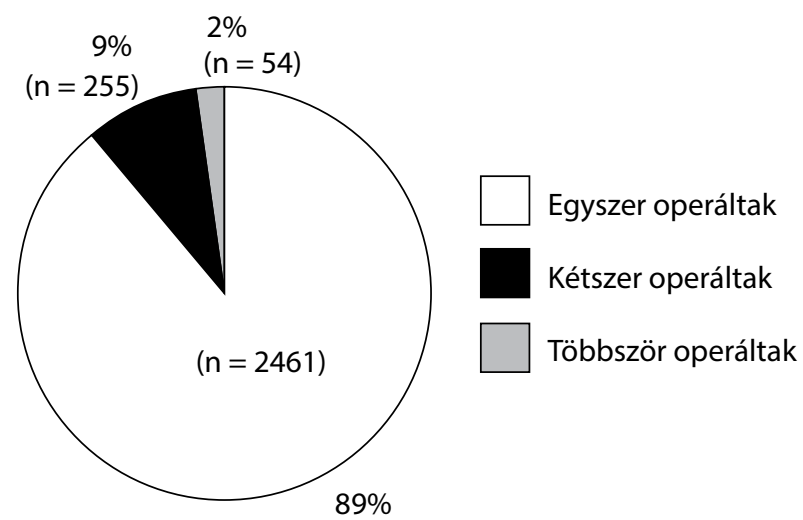

2. ábra
Egy adott beteg ellátása során végzett mútétek számának meg oszlása: congenitalis vitium miatt a betegek $89 \%$-át egy (2461 beteg), $9 \%$-át kettő (255 beteg), míg 2\%-át három, négy vagy öt alkalommal ( 54 beteg) operálták se merül fel vagy a betegünk teherbe esik, akkor a gondozásába az SZTE, ÁOK, Szülészeti és Nőgyógyászati Klinika is bekapcsolódik, akivel jól kiépített munkakapcsolatunk van a GUCH-osok (GUCH: grown-up congenital heart disease) terhesgondozása terén.

\section{A CSONGRÁD Regiszter}

Intézetünkben a betegek gondozása sok évre nyúlik viszsza, mivel Felkai Béla professzor már az 1980-as évek elején korfákat készített a dél-alföldi régióban operált congenitalis betegeiről (3. ábra) [8]. Az általunk elindított regiszter alapján mi is készítettünk hasonló korfát (4. ábra), amely azt mutatja, hogy a vártnak megfelelően a harminc évvel ezelőtti adatokhoz képest több a felnőtt- 
3. táblázat | Kisebb számban végzett mütétek évtizedes lebontásban

\begin{tabular}{|c|c|c|c|c|c|c|c|}
\hline Sorszám & Congenitalis betegség & 1961-1969 & $1970-1979$ & 1980-1989 & $1990-1999$ & $2000-2013$ & $\begin{array}{l}\text { Mútéttípusok } \\
\text { száma összesen }\end{array}$ \\
\hline 1. & Pulmonalis atresia & 2 & 10 & 18 & 19 & 15 & 64 \\
\hline 2. & Kettős kiáramlású jobb kamra & 0 & 2 & 6 & 12 & 8 & 28 \\
\hline 3. & Tricuspidalis atresia & 0 & 5 & 7 & 7 & 0 & 19 \\
\hline 4. & Univentricularis szív & 0 & 2 & 2 & 2 & 6 & 12 \\
\hline 5. & Dupla aortaív & 0 & 1 & 3 & 6 & 0 & 10 \\
\hline 6. & Arteriovenosus fistula (coronaria) & 1 & 3 & 3 & 0 & 0 & 7 \\
\hline 7. & Hypoplasiás aortaív & 1 & 0 & 0 & 4 & 0 & 5 \\
\hline 8. & Ebstein-anomália & 0 & 1 & 0 & 3 & 3 & 7 \\
\hline 9. & Truncus arteriosus communis & 0 & 0 & 0 & 4 & 1 & 5 \\
\hline 10. & Hypoplasiás jobb kamra & 0 & 0 & 1 & 1 & 3 & 5 \\
\hline 11. & $\begin{array}{l}\text { Vascularis ring, jobb oldali } \\
\text { aortaív+aberráns bal a. subclavia }\end{array}$ & 0 & 0 & 0 & 3 & 0 & 3 \\
\hline 12 . & Azygos-continuitás & 0 & 0 & 0 & 3 & 0 & 3 \\
\hline 13. & Interruptio aortae & 0 & 1 & 0 & 1 & 0 & 2 \\
\hline 14. & Mitralis atresia & 0 & 0 & 0 & 2 & 0 & 2 \\
\hline 15. & Endocardialis fibroelastosis & 1 & 0 & 1 & 0 & 0 & 2 \\
\hline 16. & Pseudotruncus & 1 & 0 & 0 & 0 & 0 & 1 \\
\hline 17. & Aortaatresia & 0 & 0 & 0 & 1 & 1 & 2 \\
\hline
\end{tabular}

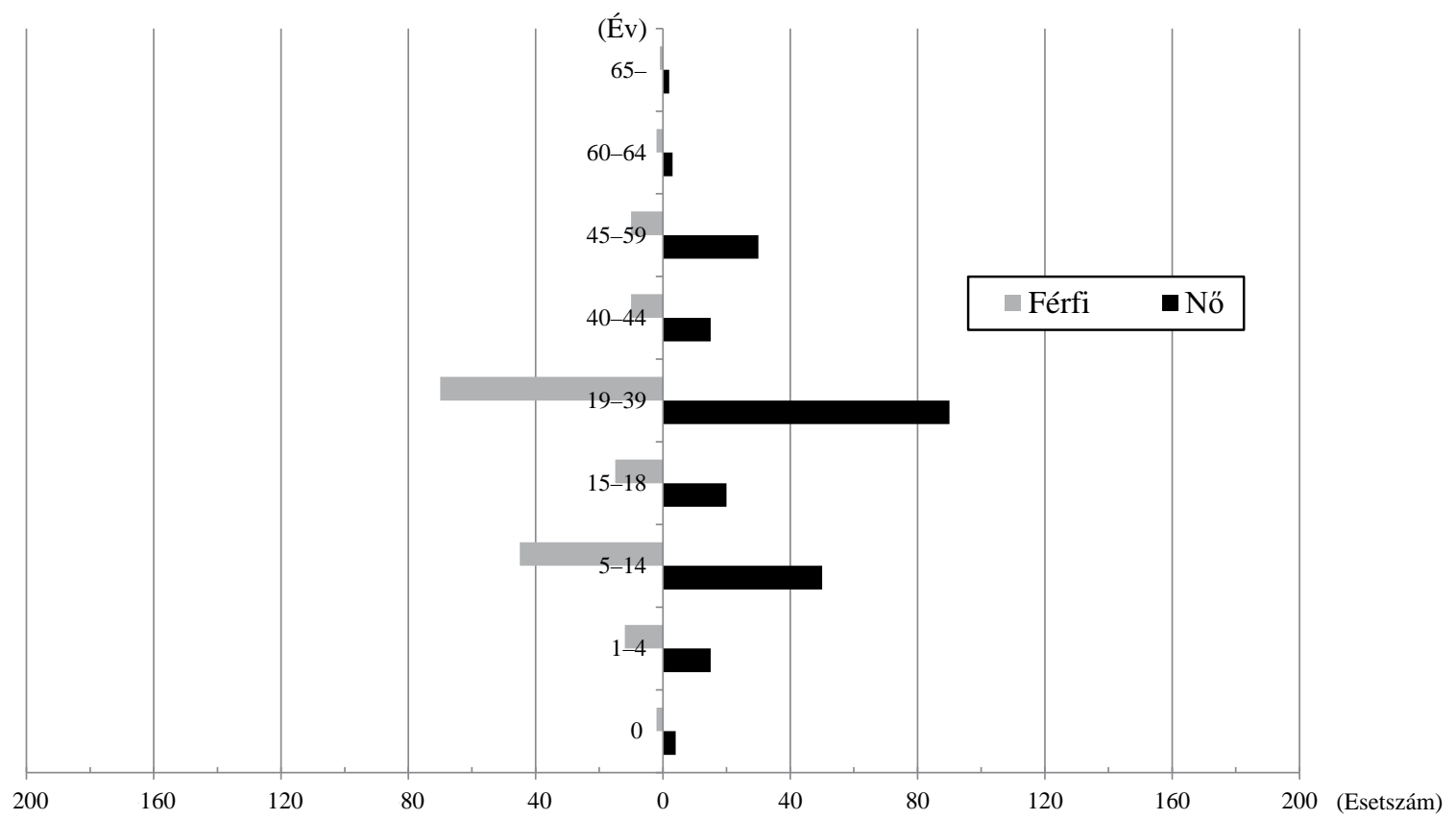

3. ábra | Congenitalis vitium miatt operált betegek korfája 1983-ban Szegeden. Az ábrán a betegek aktuális életkora szerepel 1983-ban

kort megért congenitalis szívbeteg és több a 60 éven felüli, korábban operált betegek száma.

Az irodalom alapján megállapítható, hogy a congenitalis szívbetegek gondozásával kapcsolatban relatíve kevés, nagy betegszámú követéses vizsgálatot végeztek [9]. Emiatt szükség van olyan regiszterekre, amelyek nagy esetszámon vizsgálják a különböző kórképeket, és lehetőséget nyújtanak hosszú távú utánkövetéses vizsgálatok elvégzésére, amelyek később a gondozás során evidencia alapjául is szolgálhatnak. A fenti tények támasztották alá azt a törekvésünket, hogy létrehozzuk a dél-alföldi régió congenitalis szívbetegeit tartalmazó úgynevezett 


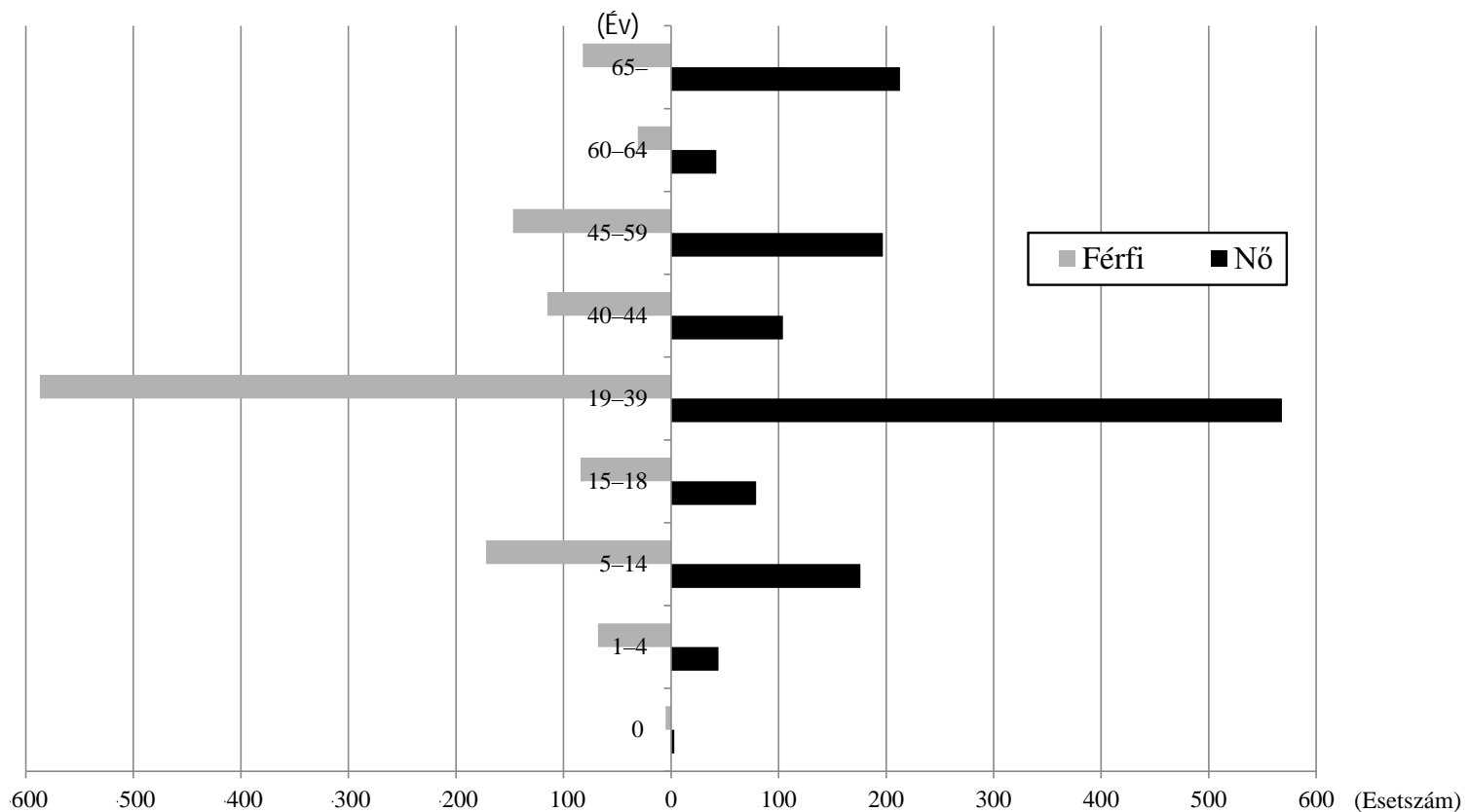

4. ábra

Congenitalis vitium miatt operált betegek korfája 2013-ban Szegeden. A mútétek száma közel tízszeresére növekedett. Mindkét korfán jól látható (3. és 4. ábra), hogy a legtöbb operált beteg 19-39 éves kor között van. 2013-ra az 1983-as adatokhoz képest a 60 évnél idősebb betegek száma lényegesen megemelkedett

CSONGRÁD Regisztert. A regiszter felépítéséből adódóan betegre, évre, mútéti típusra és számra vonatkozóan is kaphatunk adatokat. Ezen adatok alapján retrospektív vizsgálatokat végezhetünk és további prospektív vizsgálatok alapjául is szolgálhatnak. A regiszter alapját a mütött betegek listája képzi 1962-től 2014-ig, valamint folyamatban van a regiszter kiegészítése a mútött, de jelenleg még gyermekkardiológiai gondozás alatt álló betegek és a nem mütött betegek csoportjával. A regiszterben, hasonlóan a dán és svéd regiszterekhez, betegségcsoportokra lebontottan követhetjük az adott betegségtípus hosszú távú morbiditási és mortalitási adatait $[4,5]$. Az adatbázis összeállításakor figyelembe vesszük a betegek funkcionális stádiumát, esetleges aritmiáit, elektrofiziológiai beavatkozásait, reoperációit, társbetegségeit stb. Célunk, hogy az összes nagyobb betegcsoport hoszszú távú részletes utánkövetését elvégezzük, figyelembe véve többek között a residualis vitiumokat, a funkcionális stádiumot, az esetleges aritmológiai eseményeket, a terhességeknél jelentkező szülészeti szövődményeket, az életmódbeli aktivitást stb.

A dán felnőtt congenitalis szívbetegek regiszterében (Danish Registry of Adult Congenital Heart Disease) 5300 , congenitalis szívbetegség miatt operált beteg adata szerepel [4]. A dán regiszterben és a CSONGRÁD Regiszterben a congenitalis vitiumok prevalenciája hasonlónak bizonyult. Igazolást nyert az is, hogy a congenitalis vitium miatt kezelt betegek átlagéletkora növekvő tendenciát mutat. Az elmúlt 10 évben az operált vitiumok aránya, hasonlóan az adatainkhoz, Dániában is jelentősen megnövekedett. A dánok szerint a prognózist jelentősen befolyásolta a vitiumok összetettsége, kombi- nált vitiumok esetén a prognózis rosszabb, és több alkalommal is szükség lehet mütéti beavatkozásra, mint egyszerü vitiumok esetében.

Hasonló regiszter került összeállításra Svédországban (Swedish Registry on Grown-Up Congenital Heart Disease, SWEDCON), ahol a betegek több mint fele 35 év alatti, és a leggyakoribb vitium a pitvari septumdefektus (ASD), a perzisztáló foramen ovale (PFO), a ductus arteriosus persistens (PDA) és a kamrai septumdefektus (VSD) voltak [5]. A svéd regiszter adatai szerint a betegek közel 75\%-a NYHA I. funkcionális stádiumban van. Ezzel párhuzamosan a NYHA III-IV. funkcionális stádiumban lévő betegek abszolút száma növekvő tendenciát mutat. Mindez az egyre korszerúbb terápiás lehetóségeknek köszönhető.

\section{Következtetések}

A felnőttkori congenitalis vitiumok gondozása egy felnőtteket ellátó kardiológus számára újszerü, néha szokatlan problémákkal járó feladat [10]. A szegedi szívcentrumban több mint 50 éve folyik a veleszületett szívbetegségben szenvedők ellátása és gondozása. Az elmúlt évtizedek tapasztalata arra sarkallta a szerzőket, hogy egy egységes regiszterbe foglalják össze az elmúlt évek betegellátó tevékenységének eredményeit és tapasztalatait, ezzel segítve a jövő kutatóinak és orvosainak munkáját, és remélhetően az intézetünkbe kerülő betegeink ellátását. Fontosnak tartjuk a betegeink személyiségi jogának sérthetetlenségét, így adataink csak a klinikai kutatásban és a betegellátásban részt vevők számára érhető el megfelelő titoktartás mellett. 
Anyagi támogatás: A közlemény megírása anyagi támogatásban nem részesült.

Szerzői munkamegosztás: H. K.: A kézirat elkészítése. K. A., B. K., D. P.: Adatgyújtés. K. G., B. G., H. I., K. E., K. M., R. K., Cs. M., F. T., N. A.: A kézirat megszövegezése. A cikk végleges változatát valamennyi szerző elolvasta és jóváhagyta.

Érdekeltségek: A szerzőknek nincsenek érdekeltségeik.

\section{Irodalom}

[1] Gatzoulis, M. A., Webb, G. D., Daubeney, P. E. (eds.): Diagnosis and management of adult congenital heart disease. Elsevier, Edinburgh, 2011.

[2] Professional Body of Cardiology: Congenital heart disease in adults. Cardiology guidelines. [Kardiológiai Szakmai Kollégium: Felnőttkori congenitalis szívhibák. Kardiológiai Utmutató.] Medition Kiadó, Budapest, 2010. [Hungarian]

[3] Engelfriet, P., Boersma, E., Oechslin, E., et al.: The spectrum of adult congenital heart disease in Europe: morbidity and mortality in a 5 year follow-up period. The Euro Heart Survey on adult congenital heart disease. Eur. Heart J., 2005, 26(21), 23252333.

[4] Olsen, M., Videbak, J., Johnsen, S. P.: The Danish register of congenital heart disease. Scand. J. Public Health, 2011, 39(Suppl. 7), 50-53.
[5] www.ucr.uu.se/swedcon/

[6] Kovács, G.: History of heart surgery in Szeged. In: Kerkovits, Gy. (ed.): History of the 50-year-old Hungarian Cardiologist Society (1957-2007). [A szívsebészet története Szegeden. In: Kerkovits, Gy. (szerk.): A Magyar Kardiológusok Társaságának ötvenéves története 1957-2007.] Convention Budapest Kft., Budapest, 2007. [Hungarian]

[7] Nemes, A., Katona, M., Kalapos, A., et al.: Three-dimensional speckle tracking echocardiographic analysis of a fetal heart with hypoplastic left heart syndrome - a case from the MAGYAR-Fetus Study. Int. J. Cardiol., 2014, 176(3), e81-e82.

[8] Felkai, B.: Congenital heart disease in adults. [Veleszületett szívhibák felnőttkorban.] Medicus Universalis, 1986, 19(4), 195-201. [Hungarian]

[9] Baumgartner, H., Bonhoeffer, P., De Groot, N. M., et al.: ESC Guidelines for the management of grown-up congenital heart disease (new version 2010). Eur. Heart J., 2010, 31(23), 29152957.

[10] Hartyánszky, I., Varga, S., Havasi, K., et al.: Perspectives in the management of congenital heart defects in adult patients. [Perspektívák a veleszületett szívhibák felnőttkori sebészi kezelésében.] Orv. Hetil., 2015, 156(3), 92-97. [Hungarian]

(Nemes Attila dr., Szeged, Semmelweis u. 6., 6725 e-mail: nemes.attila@med.u-szeged.hu)

\section{Tisztelt Szerzőink, Olvasóink!}

Az Orvosi Hetilapban megjelenő/megjelent közlemények elérhetőségére több lehetőség kínálkozik.

Rendelhető különlenyomat, melynek áráról bővebben a www.akkrt.hu honlapon (Folyóirat Szerzőknek, Különlenyomat menüpont alatt) vagy Szerkesztőségünkben tájékozódhatnak.

A közlemények megvásárolhatók pdf-formátumban is, illetve igényelhető Optional Open Article (www.oopenart.com).

Adott dij ellenében az online közlemények bárki számára hozzáférhetők honlapunkon (a közlemények külön linket kapnak, így más oldalról is linkelhetővé válnak).

Bővebb információ a hirdetes@akkrt.hu címen vagy különlenyomat rendelése esetén a Szerkesztőségtől kérhető. 